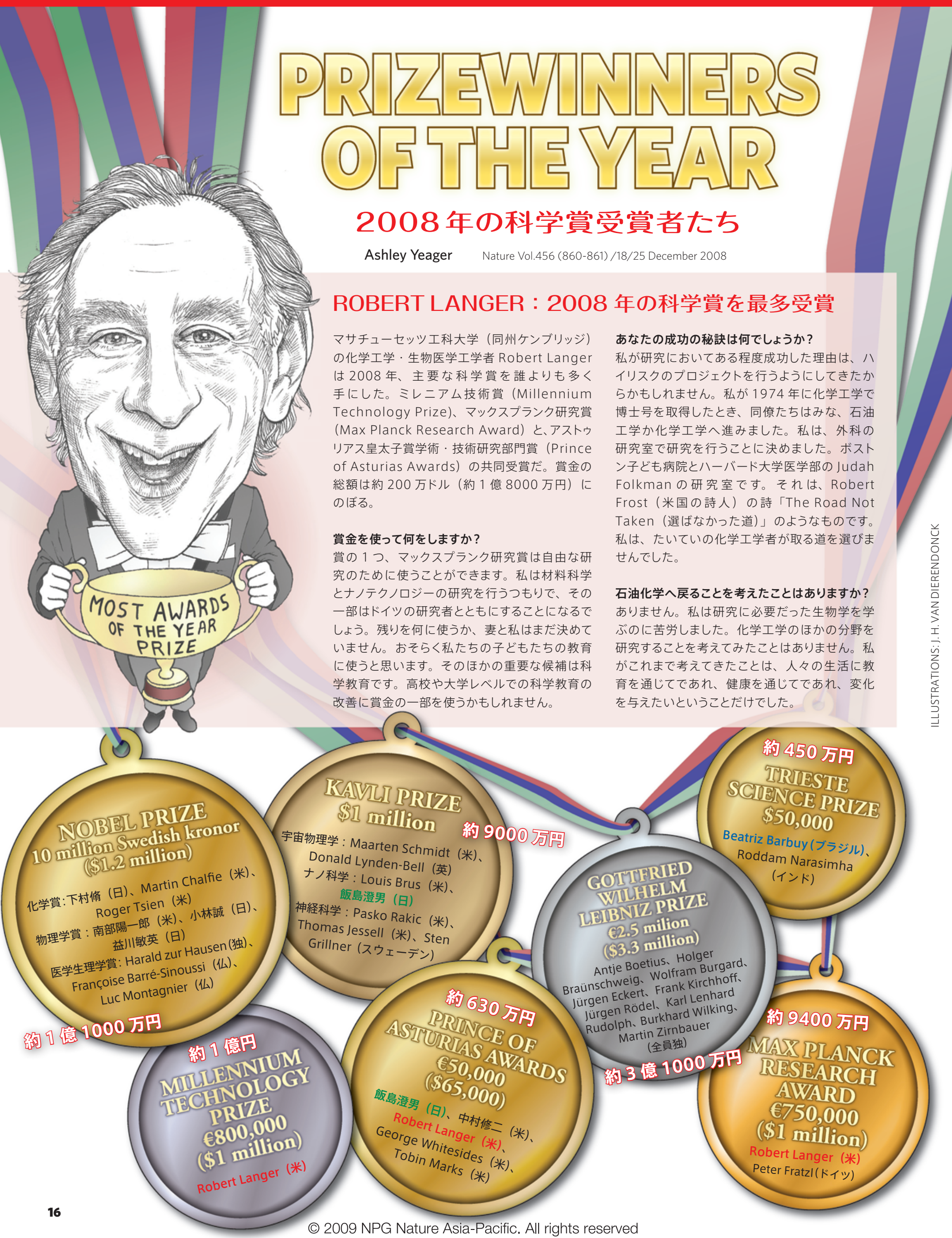




\section{BEATRIZ BARBUY：期待の新星}

ブラジルの宇宙物理学者 Beatriz Barbuy は、 発展途上国のための科学アカデミー「TWAS」 （事務局・イタリア）が今年発表したトリエステ 科学賞 (Trieste Science Prize) の 2 人の受 賞者の 1 人だ。Barbuy はサンパウロ大学に所 属し、星の化学組成の進化と銀河形成に関する 研究を認められて賞を受けた。

発展途上国の研究者を表彰する賞を受けること には、どういう意味がありますか?

それは本当にとても意義深いことです。私のよう に、よい研究を行うためにとても努力している研 究者がたくさんいます。また私たちは、よりよい 研究設備を得るために闘ってきました。今回私
が受賞したことは、ブラジルで天文学を行う環 境をよりよくする後押しとなるでしょう。

受賞を知ったとき、あなたはどう反応しましたか? 私は自分が候補として推薦されていることは知っ ていました。しかし、実際に選ばれて驚きました。 これは私にとって初めての受賞なのです。

ブラジルの天文学が大きく発展できるかについ て、どう考えていますか?

私たちはもっとよい観測環境を本当に必要として います。今、高価な観測装置を手にするには、 ほかの国々との共同研究プロジェクトを行うこと です。これは間違いありません。

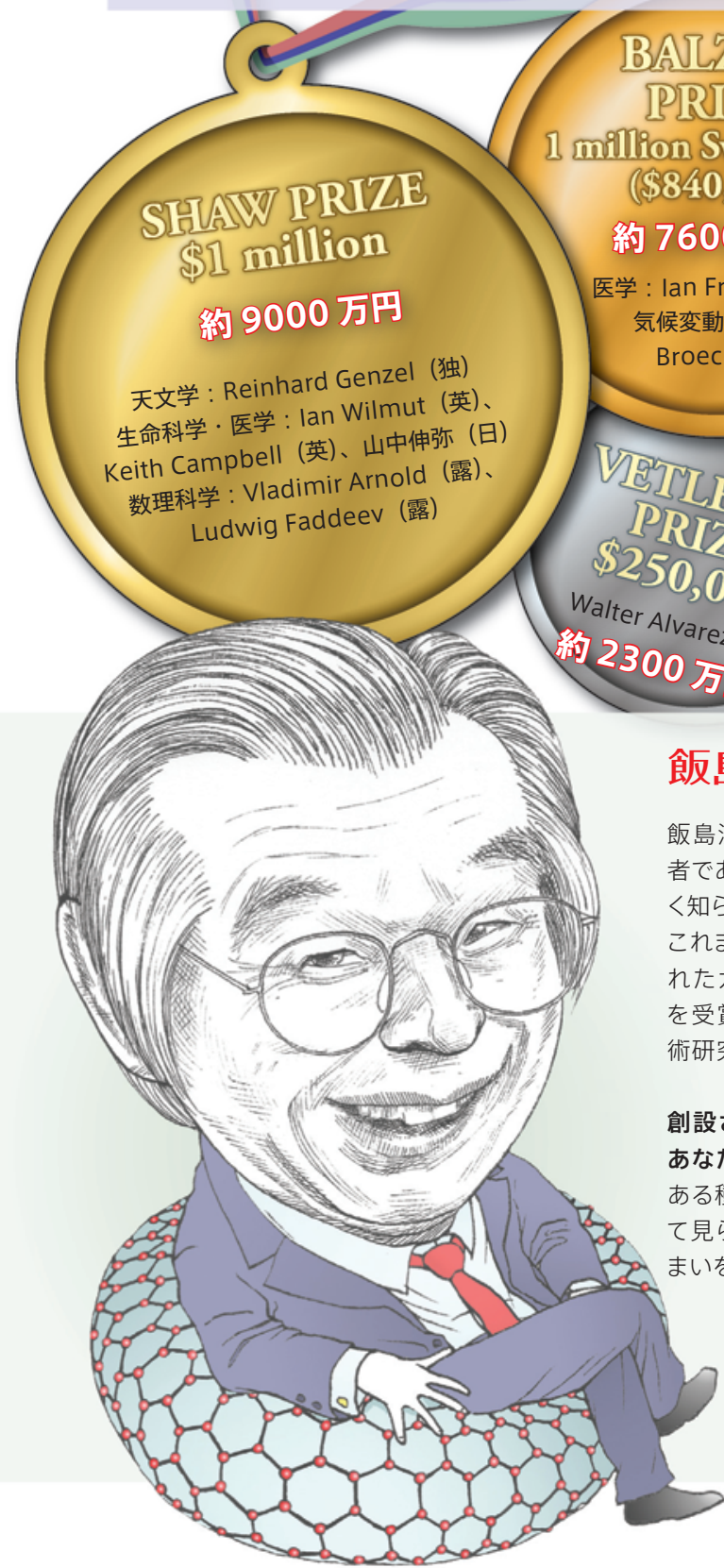

\section{का}
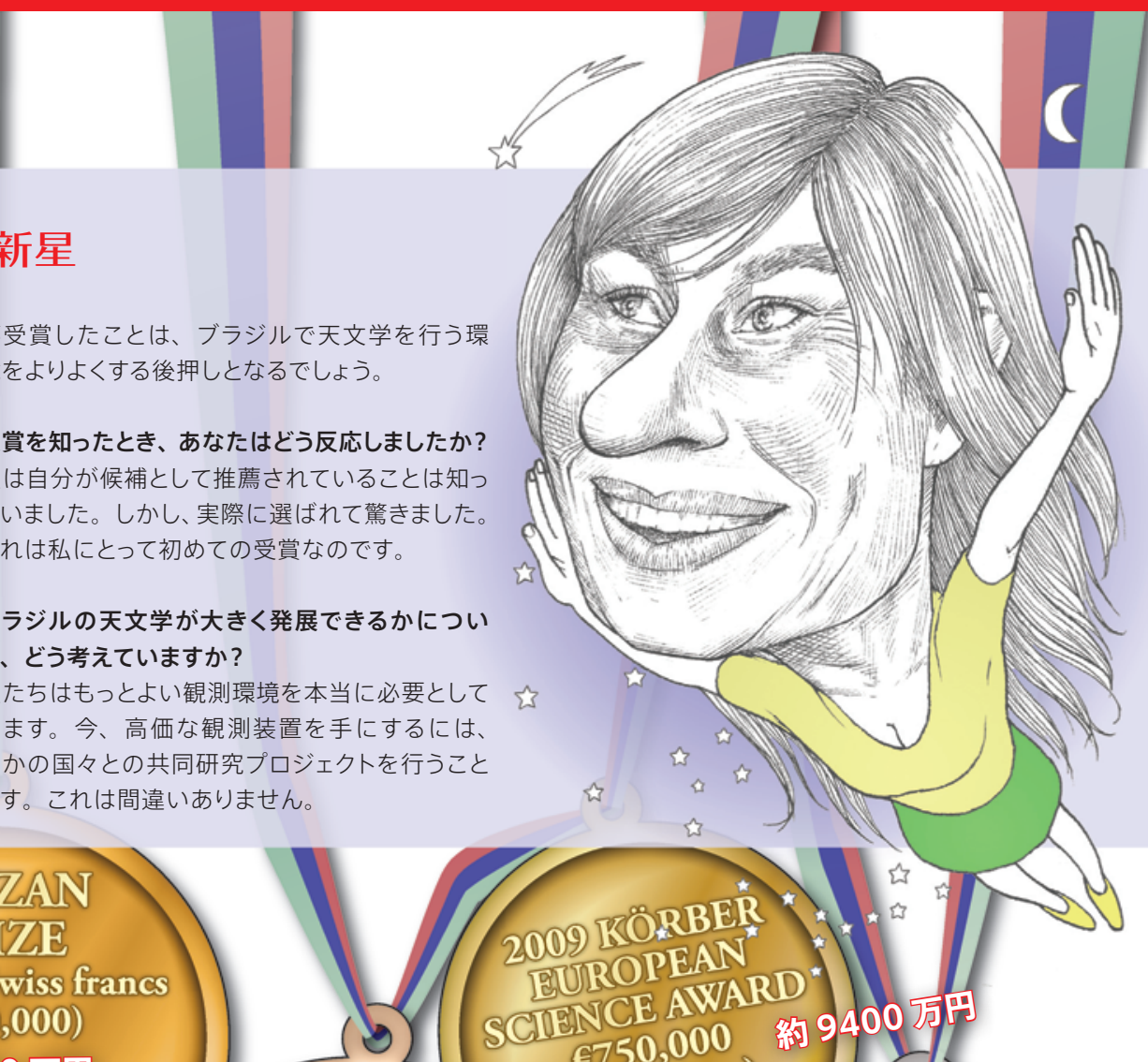

FUUROPEAN SCIOINCE AW

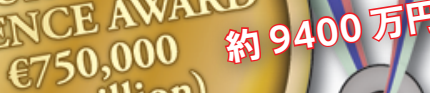

(\$1 million)

5000 局问
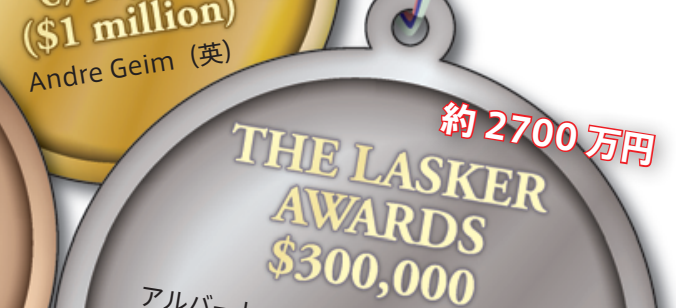

PRT2 ESIE , 000 万田
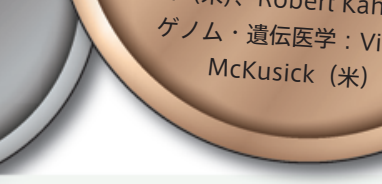

飯島澄男：小さな研究に大きな賞

飯島澄男・名城大学 (名古屋市) 教授は物理学 者であり、カーボンナノチューブの発見者として広 〈知られ、たくさんの賞を受賞している。2008 年、 これまで受賞した数々の賞に加えて、今回創設さ れたカブリ賞 (Kavri Prize) のナノ科学部門賞 を受賞し、またアストゥリアス皇太子賞学術·技 術研究部門賞を共同受賞した。

創設されたばかりのカブリ賞を受賞したことは、 あなたにとってどのような意味がありますか?

ある種の責任を感じています。今後は受賞者とし て見られるでしょうから、それにふさわしいふる いをしなければなりません。

2 つの大きな賞を受賞したことはどのよう な気持ちですか?

とてもうれしく、わずか 1 年のうちに 2 つ の賞をいただけたことを光栄に思います。
私にとって唯一残念なのは、両賞が日本ではそれ ほど知られていなかったことです。

\section{あなたはそのお金で何をしますか？}

私自身と家族のために取っておくつもりです。私 の年金がそれほど十分ではないことがその理由の 1 つです。しかし、日本の税制では、賞金の 3 分 の 1 近くが税金として取られてしまいます。これ はひどい。

あなたのように成功したいと望んでいる研究者た ちに、どのようなアドバイスをしますか?

「あなたが最もよいと思うことをすべきだ」という のが私のアドバイスです。自分自身を信じるべき です。あなたが実験家であればその分野で最高 のテクニシャンになるよう自分を訓練すべきです。 私は「挑戦」という言葉が好きなのです。 